\section{Review}

Correspondence

Mortada H. F. El-Shabrawi

melshabrawi@medicine.cu.edu.eg

\title{
Gastrointestinal basidiobolomycosis in children: an overlooked emerging infection?
}

\author{
Mortada H. F. El-Shabrawi and Naglaa Mohamed Kamal \\ Faculty of Medicine, Cairo University, Cairo, Egypt
}

\begin{abstract}
Basidiobolus ranarum is a known cause of chronic subcutaneous zygomycosis. During the past decade, many cases have been reported with extracutaneous basidiobolomycosis. We aimed to review the medical literature on gastrointestinal basidiobolomycosis (GIB) as an emerging fungal infection causing a serious, and occasionally fatal, paediatric disease. We reviewed all reported cases of visceral basidiobolomycosis with special focus on the gastrointestinal involvement in children. Twenty-six cases of GIB have been reported worldwide, in 14 adults and 12 children. All cases presented with fever, abdominal pain with mass and high blood eosinophilia and were misdiagnosed as other chronic granulomatous diseases or malignancies. A few cases of retroperitoneal, pulmonary, nasal and disseminated basidiobolomycosis have also been reported. Basidiobolomycosis mostly affects young males as a subcutaneous infection. The visceral form of infection is rare. GIB has been scarcely reported in the medical literature, but recently it has been increasingly recognized. GIB poses diagnostic difficulties. Abdominal pain with mass and eosinophilia were present in all cases, highlighting the necessity of considering GIB in the differential diagnosis of this presentation. B. ranarum has been reported to cause disseminated fatal disease in both immune-competent and -compromised individuals. Culture is the gold standard for diagnosis, but the characteristic histopathological picture of chronic granulomas rich in eosinophils and the Splendore-Hoeppli phenomenon are the usual diagnostic tools. Surgery plus long courses of itraconazole treatment, up to 1 year, appear to be the best management options. GIB is an emerging infection that might lead to diagnostic confusion, morbidity and mortality. Diagnosis requires a high index of suspicion in the differential diagnosis of patients with fever, abdominal pain with mass and eosinophilia.
\end{abstract}

\section{Introduction}

Basidiobolus is a fungus of the order Entomophthorales causing chronic subcutaneous zygomycosis of worldwide environmental distribution. Human disease is concentrated in tropical and subtropical regions. It is endemic in Uganda and certain areas of Africa, India and other parts of Asia, but is found worldwide, even in areas where the disease has not surfaced (Sugar, 1995). Basidiobolus has been isolated from leaves and decaying plants in southern and northeastern states of the USA (Gruhn \& Sanson, 1963) as well as Australia (Zahari et al., 1990).

Basidiobolus ranarum was first described as an isolate from frogs in 1886 (Gugnani, 1983). It was later cultured from the intestinal contents (Sutherland-Campbell, 1929) and ultimately the excreta (Thaxter, 1888) of frogs. The organism spends part of its life cycle in the intestine of the agamid lizard and is liberated as spores and mycelia in the lizard excreta. The spores germinate, and the organism grows saprophytically on lizard droppings, from which it may be picked up by individuals with traumatic lesions (Echetebu \& Ononogbu, 1982). In addition to being isolated from insects and reptiles, Basidiobolus has been isolated from several mammalian species. It has been found in bats (Zahari et al., 1990), horses (Miller \& Pott, 1980; Vismer et al., 1980), dogs (Miller \& Turnwald, 1984) and humans (Nazir et al., 1997).

The mode of transmission for Basidiobolus has not been absolutely confirmed, but is assumed to be via minor trauma and insect bites (Clark, 1968; Cameroon, 1990). Fungal spores are found on bristles of mites and are probably also carried by other insects. Infected insects are eaten by reptiles and amphibians, which subsequently pass the spores in their excreta (Drechsler, 1956). Clark (1968) described a case involving the hand of a patient bitten by a caterpillar. The patient had caught the insect and squeezed the 'juice' onto the site of the bite. The organism may also be transmitted from soil and vegetation that is contaminated with animal faeces (Vismer et al., 1980). Mugerwa (1976) noted that Basidiobolus may be picked up on contaminated 'toilet leaves' used for skin cleansing after a bowel movement resulting in direct inoculation in the perineum. Consistent with this theory is the fact that the buttocks, thighs and perineum are often the sites of infection in patients (Cameroon, 1990; Goodman \& 
Rinaldi, 1991). The occurrence of rhinocerebral disease in a hyperglycaemic host suggests that inhalation of spores, as seen in many cases of zygomycosis with the Mucorales, may also play a role in infection for some patients with Basidiobolus (Dworzack et al., 1978). Iatrogenic infection has been reported. Nazir et al. (1997) reported a case of possible inoculation during appendectomy, and Kamalam \& Thambiah (1984) reported inoculation from a needle injection. B. ranarum typically causes a chronic infection of the peripheral or subcutaneous tissue, usually on the arms, trunk and buttocks (Goodman \& Rinaldi, 1991). Skin and subcutaneous tissue infection is characterized by a hardened nodule which expands and spreads locally. Although the nodules will eventually ulcerate the overlying skin, dissemination usually does not occur (Chandler \& Watts, 1987).

Low virulence of Basidiobolus has been postulated based on the small number of cases worldwide, which approximates 300 (Sugar, 1995; Nazir et al., 1997). This lack of virulence is also suggested by experiments in mice. Following experimental inoculation of Basidiobolus in mice, invasive disease was not seen (Arney et al., 1960). It has been suggested that some unknown abnormality must account for the disease (Sugar, 1995) and that invasive and progressive infection in previously healthy individuals may result from transient immune suppression during viral infections or following surgery (Sugar, 1990). If immune suppression indeed accounts for this mycosis, infection with Basidiobolus may become more prevalent due to the human immunodeficiency virus pandemic (Nazir et al., 1997). Yangco et al. (1986) demonstrated production of exo-antigens by Basidiobolus. In vitro production of proteases (Okafor et al., 1987; Okafor, 1994) and lipases (Okafor et al., 1987; Okafor \& Gugnani, 1990) has also been seen, allowing it to survive and thrive under various growth conditions (Echetebu \& Ononogbu, 1982). Echetebu \& Ononogbu (1982) also suggested that growth of the organism and release of enzymes in vivo may be related to the level of fat deposits under the skin and that one of its lipases is phospholipase A. A product of hydrolysis of phosphatidylcholine by phospholipase $\mathrm{A}$ is lysolecithin, a protein which is able to digest human serum proteins, and the authors hypothesized that hydrolysis of lecithin to lysolecithin destroys cell membranes (blood, skin and muscle cells) and may be the pathogenic mechanism used by the organism. The authors reasoned that protein components of liberated extracellular contents are digested by proteinases produced by Basidiobolus and serve as nutrients for organism growth. Basidiobolus is relatively thermotolerant and is capable of growing, although poorly, at $37^{\circ} \mathrm{C}$ (Kwon-Chung \& Bennett, 1992; St Germain \& Summerbel, 1996). It is hypothesized that thermotolerance is an important virulence factor for these organisms, allowing them to establish infections in vivo with those possessing growth capabilities above $37^{\circ} \mathrm{C}$ having the advantage of survival in the febrile patient (Reinhardt et al., 1970).
Basidiobolomycosis rarely involves extracutaneous systems. Gastrointestinal (GIB) (Hussein et al., 2007), retroperitoneal (Finelli et al., 1997; Nazir et al., 1997) and pulmonary (Bigliazzi et al., 2004) basidiobolomycosis have been reported in the medical literature. Surgery and prolonged antifungal therapy are usually required for treatment (van den Berk et al., 2006). To the best of our knowledge, only 26 cases of GIB have been reported worldwide: 14 adult cases (eight from the USA, two from Brazil, two from Kuwait, one from Nigeria and one from the Netherlands; Kian Joe et al., 1956; Greer \& Friedman, 1966; Dworzack et al., 1978; Zahari et al., 1990; Khan et al., 2001; Lyon et al., 2001) and 12 paediatric cases (eight from Saudi Arabia, two from Brazil, one from Iran and one from Nigeria; Zahari et al., 1990; Khan et al., 2001; Al Jarie et al., 2003; Wasim Yusuf et al., 2003). A report on the 12th paediatric case, which is the 8th paediatric case in the kingdom of Saudi Arabia (KSA), is in press (El-Shabrawi et al., 2011).

In this article, we will review the literature on GIB, which might be an emerging serious, and occasionally fatal, paediatric fungal infection.

\section{Clinical, laboratory, imaging and histopathological findings in GIB}

All patients reported with GIB had fever and abdominal pain as their main symptoms, with no response to conventional therapy. Peripheral blood leukocytosis with marked eosinophilia as well as elevated erythrocyte sedimentation rate and C-reactive protein were found in all cases (Wardlaw \& Kay, 1995; Lyon et al., 2001). On physical examination, intra-abdominal masses were always detected and confirmed by imaging studies including ultrasonographic and computed tomography (CT) scanning as well as during surgical exploration. In all cases, a provisional diagnosis of either a chronic inflammatory or malignant process was suggested. The main clue for diagnosis was a meticulous histopathological examination revealing: (i) inflammatory changes with many eosinophils (Wardlaw \& Kay, 1995) and broad pleomorphic, sparsely septated hyphae (Kwon-Chung \& Bennett, 1992; Yousef et al., 1999) on silver staining; (ii) fungal elements often appearing as empty spaces surrounded by an intensely staining eosinophilic material (Splendore-Hoeppli phenomenon) on haematoxylin and eosin staining, as seen in Fig. 1 (Kwon-Chung \& Bennett, 1992; Yousef et al., 1999).

All paediatric GIB patients were male with no significant medical history or apparent predisposing factor(s). Seven of them were from the KSA; six were reported by $\mathrm{Al}$ Jarie et al. (2003) (Table 1). The seventh, reported by Hussein et al. (2007), was a 13-year-old boy with GIB presenting with sudden-onset acute abdominal pain with diffuse abdominal rigidity and tenderness. At surgery, a mass was seen in the lower part of the ascending colon. Hemicolectomy was performed and antifungal treatment with itraconazole was started. The patient remained well on long-term follow-up. We consider our patient the eighth 
(a)

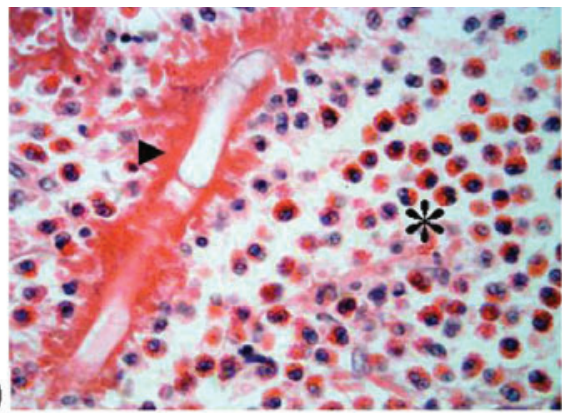

(c)

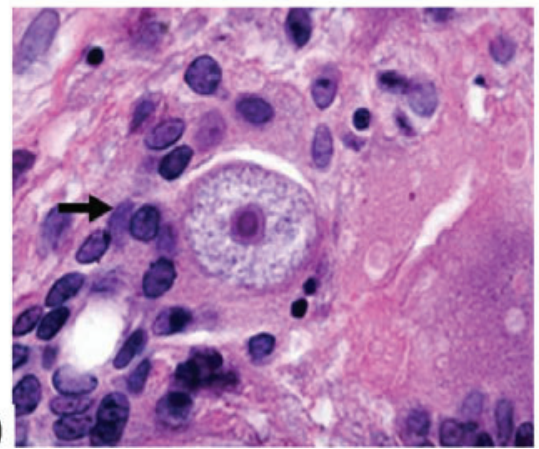

(b)

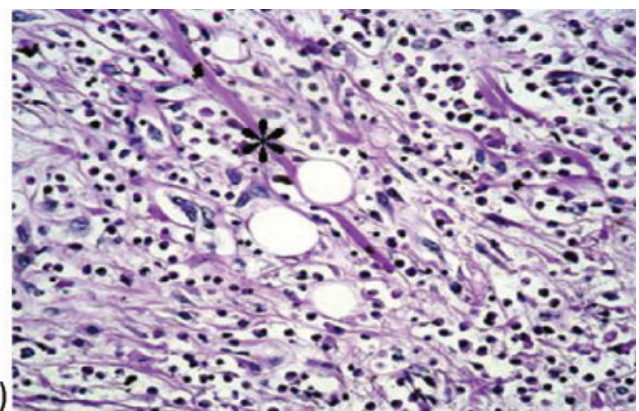

(d)

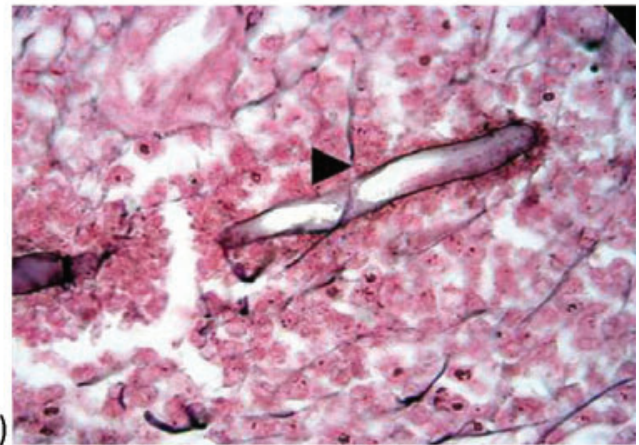

Fig. 1. (a) Colonic Basidiobolus ranarum appearing as broad, septate hyphae surrounded by an eosinophilic sheath (Splendore-Hoeppli phenomenon) and numerous eosinophils. (b) Broad fungal hyphae of B. ranarum (periodic acid-Schiff diastase stain). (c) Multinucleated giant cells phagocytosing fungal zygospores. The latter appear as spherical bodies that measure up to $30 \mu \mathrm{m}$ in diameter. They have a thin outer wall, foamy cytoplasm, and a nucleus containing a large nucleolus (haematoxylin and eosin stain). (d) Broad, septate fungal hyphae (black; Grimelius methenamine silver stain). Figure reprinted from Hussein et al. (2007) with permission from Elsevier/The British Mycological Society.

paediatric case with GIB in the KSA. Similarly, the patient presented with fever, recurrent abdominal pain with mass and vomiting and was diagnosed after intensive investigations (El-Shabrawi et al., 2011). The remaining four paediatric cases were reported from Nigeria (one case) (Edington, 1964), Brazil (two cases) (Bittencourt et al., 1979; de Aguiar et al., 1980) and Iran (one case) (Fahimzad et al., 2006) as shown in Table 2.

In 1986, the first culture-proven case of GIB in the USA was reported by Schmidt and his colleagues (Schmidt et al., 1986). The patient was a 69-year-old diabetic man with lesions involving the duodenum, ileum, caecum and ascending colon. He was treated with amphotericin B, but died within 6 weeks. In 1997, Pasha et al. (1997) reported basidiobolomycosis of the rectosigmoid region in a 49-year-old woman from Arizona, USA. After surgical resection of the lesion and itraconazole treatment, no evidence of residual disease was seen on follow-up. In 1998, Khan and his group reported a case of GIB of the rectum masquerading as Crohn's disease in a Bangladeshi male living in Kuwait (Khan et al., 1998). In 1999, Zavasky and coworkers reported the third case of GIB in the USA, which was initially treated as inflammatory bowel disease (Zavasky et al., 1999). In the same year, Yousef et al. (1999) reported six cases of GIB (Table 3) from Phoenix, Arizona (Lyon et al., 2001), and in all, the diagnosis was established by histopathology with or without fungal culture.

Nguyen (2000) reported a 57-year-old insulin-dependent diabetic man with GIB who was misdiagnosed initially as having peptic ulcer disease with no improvement. He underwent subtotal gastrectomy and partial transverse colectomy for transmural granulomatous disease of the colon compatible with Crohn's disease with no improvement. He developed left hydronephrosis, left perinephric phlegmon, and thickening of the caecum, descending colon, sigmoid colon and rectum. A left ureteral stent was placed and right colectomy was done. Careful histopathology diagnosed B. ranarum infection and the patient improved and was discharged on itraconazole. Later, he developed intermittent nausea, anorexia, fever and continuing weight loss. Left renal obstruction, perinephric inflammation and rectosigmoid abscess were found.

Unfortunately, renal stenting and medical treatment with itraconazole and terbinafine failed and a fistula developed between the left collecting system and small bowel and finally ended with left nephrectomy.

In 2001, Khan and his colleagues in Kuwait reported a 41year-old Indian man with GIB who presented with abdominal pain and fever for 20 days (Khan et al., 2001). A mass in the right iliac fossa was identified with marked 
Table 1. Clinical and laboratory features of six patients with GIB in KSA reported by Al Jarie et al. (2003)

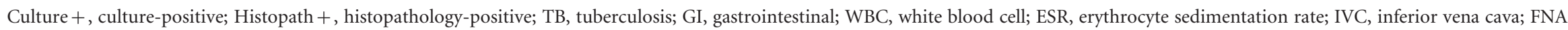

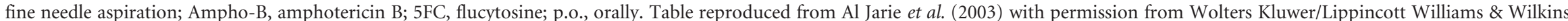

\begin{tabular}{|c|c|c|c|c|c|c|c|c|c|c|c|c|c|}
\hline Patient & Age & Sex & Date & $\begin{array}{l}\text { Method } \\
\text { of } \\
\text { diagnosis }\end{array}$ & $\begin{array}{c}\text { Clinical } \\
\text { presentation }\end{array}$ & $\begin{array}{l}10^{-3} \times \\
\mathrm{WBC} \\
\text { count } \\
(\text { cells } \\
\left.\mathrm{ml}^{-1}\right)\end{array}$ & $\begin{array}{c}\% \\
\text { Eosin- } \\
\text { ophils }\end{array}$ & $\begin{array}{r}\text { ESR } \\
(\mathbf{m m} \\
\left.\mathbf{h}^{-1}\right)\end{array}$ & $\begin{array}{l}\text { Immuno- } \\
\text { logical } \\
\text { workup }\end{array}$ & $\begin{array}{l}\text { Radiological } \\
\text { findings }\end{array}$ & $\begin{array}{l}\text { Surgical } \\
\text { procedures }\end{array}$ & Treatment & Follow-up \\
\hline 1 & 12 & $\mathrm{M}$ & $\begin{array}{l}\text { May } \\
2000\end{array}$ & $\begin{array}{l}\text { Culture + } \\
\text { Histopath }+\end{array}$ & $\begin{array}{l}\text { Abdominal pain, } \\
\text { fever } \times 2 / 12 \\
\text { Abdominal } \\
\text { distension and } \\
\text { right-sided scrotal } \\
\text { swelling } \times 1 / 12 \\
\text { Started on anti-TB } \\
\text { treatment }\end{array}$ & 16 & 15 & 76 & Normal & $\begin{array}{l}\text { Huge abdominal } \\
\text { mass occupying } \\
\text { the right upper } \\
\text { part of the } \\
\text { abdomen } \\
\text { Liver lesions } \\
\text { Retroperitoneal } \\
\text { with right } \\
\text { kidney } \\
\text { involvement }\end{array}$ & $\begin{array}{l}\text { Right } \\
\text { hemico- } \\
\text { lectomy } \\
\text { Biliary duct } \\
\text { stenting }\end{array}$ & $\begin{array}{l}\text { Ampho-B } \\
\text { Itraconazole }\end{array}$ & $\begin{array}{l}\text { Asymptomatic } \\
\text { Itraconazole } \\
\text { p.o. }\end{array}$ \\
\hline 2 & 12 & $\mathrm{M}$ & $\begin{array}{l}\text { June } \\
2001\end{array}$ & Histopath + & $\begin{array}{l}\text { Abdominal pain, } \\
\text { fever } \mathrm{C} 3 / 12 \\
\text { Operated as } \\
\text { appendicitis }\end{array}$ & 16 & 20.6 & 114 & Normal & $\begin{array}{l}\text { Right liver lobe } \\
\text { mass } \\
\text { Right kidney } \\
\text { mass }\end{array}$ & $\begin{array}{l}\text { Resection of } \\
\text { terminal } \\
\text { ileum, } \\
\text { caecum and } \\
\text { ascending } \\
\text { colon }\end{array}$ & $\begin{array}{l}\text { Ampho-B } \\
\text { Itraconazole }\end{array}$ & $\begin{array}{l}\text { Asymptomatic } \\
\text { Itraconazole } \\
\text { p.o. } \\
\text { Resolved renal } \\
\text { and } \\
\text { liver lesions }\end{array}$ \\
\hline 3 & 12 & M & $\begin{array}{l}\text { Oct } \\
2001\end{array}$ & $\begin{array}{l}\text { Culture + } \\
\text { Histopath }+\end{array}$ & $\begin{array}{l}\text { Abdominal pain, } \\
\text { fever } \times 2 / 12 \\
\text { Operated as } \\
\text { appendicitis with } \\
\text { appendicular mass }\end{array}$ & 17 & 19.7 & 85 & Normal & $\begin{array}{l}\text { Right iliac } \\
\text { fossa mass } \\
\text { engulfing } \\
\text { caecum with } \\
\text { surrounding } \\
\text { lymphaden- } \\
\text { opathy } \\
\text { Liver mass } \\
\text { Retroperitoneal } \\
\text { extension }\end{array}$ & $\begin{array}{l}\text { Right } \\
\text { hemico- } \\
\text { lectomy }\end{array}$ & $\begin{array}{l}\text { Ampho-B } \\
\text { Itraconazole }\end{array}$ & $\begin{array}{l}\text { Asymptomatic } \\
\text { Itraconazole }\end{array}$ \\
\hline
\end{tabular}




\begin{tabular}{|c|c|c|c|c|c|c|c|c|c|c|c|c|c|}
\hline Patient & Age & Sex & Date & $\begin{array}{c}\text { Method } \\
\text { of } \\
\text { diagnosis }\end{array}$ & $\begin{array}{c}\text { Clinical } \\
\text { presentation }\end{array}$ & $\begin{array}{l}10^{-3} \times \\
\mathrm{WBC} \\
\text { count } \\
(\text { cells } \\
\left.\mathrm{ml}^{-1}\right)\end{array}$ & $\begin{array}{c}\% \\
\text { Eosin- } \\
\text { ophils }\end{array}$ & $\begin{array}{r}\text { ESR } \\
(\mathrm{mm} \\
\left.\mathbf{h}^{-1}\right)\end{array}$ & $\begin{array}{l}\text { Immuno- } \\
\text { logical } \\
\text { workup }\end{array}$ & $\begin{array}{l}\text { Radiological } \\
\text { findings }\end{array}$ & $\begin{array}{l}\text { Surgical } \\
\text { procedures }\end{array}$ & Treatment & Follow-up \\
\hline 4 & 4 & $\mathrm{M}$ & $\begin{array}{r}\text { March } \\
2002\end{array}$ & $\begin{array}{l}\text { Culture + } \\
\text { Histopath + }\end{array}$ & $\begin{array}{l}\text { Fever, abdominal } \\
\text { pain } \times 1 / 12 \\
\text { Massive } \\
\text { hepatomegaly }\end{array}$ & 30 & 30 & 138 & Normal & $\begin{array}{l}\text { Hepatomegaly } \\
\text { Hepatic } \\
\text { lesion with an } \\
\text { area of } \\
\text { necrosis }\end{array}$ & $\begin{array}{l}\text { FNA liver } \\
\text { lesion }\end{array}$ & $\begin{array}{l}\text { Ampho-B } \\
\text { Itraconazole }\end{array}$ & $\begin{array}{l}\text { Asymptomatic } \\
\text { Itraconazole } \\
\text { p.o. }\end{array}$ \\
\hline 5 & 3 & $\mathrm{M}$ & $\begin{array}{c}\text { August } \\
2001\end{array}$ & $\begin{array}{l}\text { Culture + } \\
\text { Histopath }+\end{array}$ & $\begin{array}{l}\text { Abdominal pain, } \\
\text { fever } \times 3 / 12 \\
\text { Abdominal } \\
\text { distension, weight } \\
\text { loss } \times 2 / 12 \\
\text { Anti-TB } \\
\text { treatment }\end{array}$ & 24 & 18 & 105 & Normal & $\begin{array}{l}\text { Liver mass } \\
\text { Extensive } \\
\text { lesions } \\
\text { involving } \\
\text { liver, spleen, } \\
\text { gall bladder, } \\
\text { mesentery, } \\
\text { lesser sac, } \\
\text { compressing } \\
\text { IVC } \\
\text { Right kidney } \\
\text { not seen }\end{array}$ & $\begin{array}{l}\text { FNA liver } \\
\text { lesion }\end{array}$ & $\begin{array}{l}\text { Ampho-B } \\
\text { 5FC } \\
\text { Ambisome }\end{array}$ & $\begin{array}{l}\text { Died within } \\
2 \text { days of } \\
\text { diagnosis }\end{array}$ \\
\hline 6 & 7 & $\mathrm{M}$ & $\begin{array}{c}\text { August } \\
2000\end{array}$ & Histopath + & $\begin{array}{l}\text { Abdominal pain, } \\
\text { distension, fever, } \\
\text { vomiting, jaundice } \\
\text { and weight } \\
\text { loss } \\
\text { Hepatosplenomegaly } \\
\text { GI bleeding }\end{array}$ & 16.9 & 17 & 96 & Normal & $\begin{array}{l}\text { Liver lesion } \\
\text { Hepatosplen- } \\
\text { omegaly } \\
\text { Retroperi- } \\
\text { toneal } \\
\text { mass }\end{array}$ & $\begin{array}{l}\text { Endoscopy, } \\
\text { revealed } \\
\text { oesophageal } \\
\text { varices } \\
\text { + duode- } \\
\text { nobiliary } \\
\text { fistula } \\
\text { Laparotomy } \\
\text { revealed } \\
\text { extensive } \\
\text { highly } \\
\text { vascular } \\
\text { inoperable } \\
\text { lesions }\end{array}$ & $\begin{array}{l}\text { Ampho-B } \\
\text { Itraconazole }\end{array}$ & $\begin{array}{l}\text { Died at } \\
\text { referred } \\
\text { hospital with } \\
\text { massive GI } \\
\text { bleeding }\end{array}$ \\
\hline
\end{tabular}


Table 2. Summary of presumed or culture-proven cases of paediatric GIB outside KSA

\begin{tabular}{|c|c|c|c|c|c|c|c|c|}
\hline $\begin{array}{l}\text { Country and } \\
\text { reference }\end{array}$ & $\begin{array}{c}\text { Age } \\
\text { (years) }\end{array}$ & Sex & $\begin{array}{l}\text { Risk } \\
\text { factor }\end{array}$ & $\begin{array}{l}\text { Symptoms } \\
\text { and signs }\end{array}$ & Site(s) involved & $\begin{array}{l}\text { Diagnostic } \\
\text { method }\end{array}$ & Therapy & Outcome \\
\hline $\begin{array}{l}\text { Brazil } \\
\text { (de Aguiar } \\
\text { et al., 1980) }\end{array}$ & 4 & M & None & $\begin{array}{l}\text { Abdominal pain, } \\
\text { fever, sweats } \\
\text { diarrhoea, } \\
\text { epigastric mass }\end{array}$ & $\begin{array}{l}\text { Stomach, transverse } \\
\text { colon }\end{array}$ & $\begin{array}{l}\text { Histology } \\
\text { and culture }\end{array}$ & Surgery & $\begin{array}{l}\text { Died of } \\
\text { disease } 2.5 \\
\text { months after } \\
\text { presentation }\end{array}$ \\
\hline $\begin{array}{l}\text { Brazil } \\
\text { (Bittencourt } \\
\text { et al., 1979) }\end{array}$ & 13 & M & None & $\begin{array}{l}\text { Abdominal pain, } \\
\text { weakness, fever, } \\
\text { anorexia, } \\
\text { memory loss }\end{array}$ & $\begin{array}{l}\text { Stomach, duodenum, } \\
\text { transverse colon, } \\
\text { pancreas, liver, } \\
\text { biliary system, } \\
\text { intestinal obstruction }\end{array}$ & Histology & None & $\begin{array}{l}\text { Died of } \\
\text { disease } \\
\text { without } \\
\text { therapy } 4 \\
\text { months after } \\
\text { presentation }\end{array}$ \\
\hline $\begin{array}{l}\text { Nigeria } \\
\text { (Edington, } \\
\text { 1964) }\end{array}$ & 6 & M & None & $\begin{array}{l}\text { Skin infection, } \\
\text { rectal obstruction }\end{array}$ & $\begin{array}{l}\text { Skin, ileum, } \\
\text { transverse colon, } \\
\text { rectum, bladder }\end{array}$ & Histology & $\begin{array}{l}\text { Antibiotics, } \\
\text { iodide } \\
\text { therapy }\end{array}$ & $\begin{array}{l}\text { Died of } \\
\text { disease } 1 \\
\text { year after } \\
\text { presentation }\end{array}$ \\
\hline $\begin{array}{l}\text { Iran } \\
\text { (Fahimzad } \\
\text { et al., 2006) }\end{array}$ & 1.5 & M & None & $\begin{array}{l}\text { Abdominal pain, } \\
\text { fever, diarrhoea, } \\
\text { haematochezia, } \\
\text { bowel obstruction, } \\
\text { urinary retention }\end{array}$ & $\begin{array}{l}\text { Rectum with } \\
\text { bowel obstruction, } \\
\text { pressure effects } \\
\text { on the bladder }\end{array}$ & Histology & $\begin{array}{l}\text { Surgery and } \\
\text { antifungal }\end{array}$ & $\begin{array}{l}\text { On regular } \\
\text { follow-up, } \\
\text { his condition } \\
\text { was perfect } \\
\text { with no } \\
\text { complications }\end{array}$ \\
\hline
\end{tabular}

thickening of the ascending colon and caecum and bilateral increased renal echogenicity. A presumptive diagnosis of intestinal tuberculosis was made. He underwent surgical resection and a biopsy was sent for confirmation. This was negative for tuberculosis, and GIB was diagnosed by the characteristic histopathological picture of the specimen as well as similarity in clinical picture to their patient reported in 1998. Meanwhile, the patient developed difficulty in passing urine and his urine culture revealed several colonies of B. ranarum. Liposomal amphotericin B at a dose of $1 \mathrm{mg}$ ( $\mathrm{kg}$ body weight $)^{-1}$ per day was started for 4 weeks, but his condition did not improve. The dose was doubled to $2 \mathrm{mg}$ (kg body weight) ${ }^{-1}$ per day for 4 weeks, but his condition deteriorated. The $B$. ranarum isolate was later found to be resistant to amphotericin B. The patient requested to go back to his native country (India) and was lost to follow-up. This patient was apparently otherwise healthy except for chronic anaemia, and the only recognizable risk factor was the history of surgical correction of a left inguinal hernia 2 years earlier. The possibility that the fungus was implanted during the surgical procedure could not be excluded. In this context, it should be mentioned that this patient was from the southern part of India where many cases of subcutaneous B. ranarum infection have been described (Kamalam et al., 1992). This case is similar to that described by Zavasky et al. (1999), in that infection disseminated to involve the urinary tract and the diagnosis was made by isolation of $B$. ranarum from urine samples. Moreover, the isolate in both instances was resistant to amphotericin B.

van den Berk et al. (2006) reported a 61-year-old man who presented with progressive left abdominal pain and constipation for a few months. Colonoscopy showed an obstructing mass in the descending colon, and a hemicolectomy was performed. Histology showed inflammation, possibly caused by a fungal or parasitic infection, without definite identification of an organism. A few weeks postoperatively, a CT scan performed for abdominal discomfort revealed a liver mass of $6 \mathrm{~cm}$ diameter. Treatment with metronidazole, directed against an amoebic liver abscess, was unsuccessful. He developed marked eosinophilia (27.7\%). Liver biopsy was performed. Review of colonic and liver biopsy samples suggested a diagnosis of $B$. ranarum infection. Treatment with amphotericin B was started because itraconazole was contra-indicated due to renal insufficiency. A few days later, the patient died of a septic shock. After autopsy, B. ranarum was cultured from the liver, gall bladder and colon.

\section{Conclusions}

Although the histological features of $B$. ranarum are well described in the skin and subcutaneous tissue, gastrointestinal involvement has presented considerable diagnostic difficulties and confusion. It should be suspected in the differential diagnosis of any GI mass with eosinophilia. The small number of reported cases of GIB is probably related to the limited awareness of this disease and may not reflect its true incidence worldwide. Its diagnosis is usually delayed or overlooked if attention is not focused on the possibility of this fungal infection, and the diagnosis must be made on the histological picture of the fungal morphology and the Splendore-Hoeppli phenomenon, which, although not entirely specific, are characteristic 
Table 3. Clinical characteristics of patients with GIB in Arizona, 1994-1999 (Lyon et al., 2001)

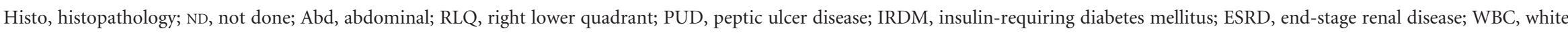

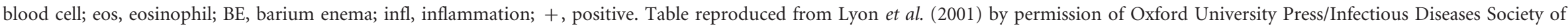
America.

\begin{tabular}{|c|c|c|c|c|c|c|c|c|}
\hline $\begin{array}{l}\text { Patient no./age } \\
\text { (years)/sex }\end{array}$ & $\begin{array}{l}\text { Date and method } \\
\text { of GIB diagnosis }\end{array}$ & $\begin{array}{l}\text { Onset of } \\
\text { symptoms }\end{array}$ & $\begin{array}{l}\text { Medical and } \\
\text { social history }\end{array}$ & $\begin{array}{l}10^{-3} \times \mathrm{WBC} \\
\text { count (cells } \mathrm{ml}^{-1} \text { ), } \\
\text { absolute eos count }\end{array}$ & $\begin{array}{l}\text { Radiological } \\
\text { findings }\end{array}$ & $\begin{array}{c}\text { Surgical } \\
\text { procedure(s) }\end{array}$ & Treatment & $\begin{array}{l}\text { Follow-up } \\
\text { findings }\end{array}$ \\
\hline $1 / 49 / \mathrm{F}$ & $\begin{array}{l}\text { 5/95: Histo }+ \\
\text { culture ND }\end{array}$ & $\begin{array}{l}\text { 9/94: Abd } \\
\text { pain, } \\
\text { constipation, } \\
\text { mucous } \\
\text { discharge }\end{array}$ & $\begin{array}{l}\text { PUD, avid } \\
\text { gardener }\end{array}$ & $\begin{array}{l}3 / 95: 13.3,2.5 ; \\
4 / 95: 23.4 \mathrm{WBC}\end{array}$ & $\begin{array}{l}\text { CT: thickened } \\
\text { rectal/sigmoid } \\
\text { wall; BE: } 30 \mathrm{~cm} \\
\text { segmental } \\
\text { stricture }\end{array}$ & $\begin{array}{l}\text { 5/95: Rectosigmoidal } \\
\text { resection, colostomy; } \\
\text { 7/95: reanastamosis }\end{array}$ & $\begin{array}{l}\text { Itraconazole } \\
\text { (400 mg per } \\
\text { day for } 3 \\
\text { months) }\end{array}$ & $\begin{array}{l}\text { Asymptomatic; } \\
\text { no medication }\end{array}$ \\
\hline $2 / 46 / \mathrm{M}$ & $\begin{array}{l}\text { 9/96: Histo +, } \\
\text { culture }+\end{array}$ & $\begin{array}{l}\text { 9/96: RLQ } \\
\text { abd pain }\end{array}$ & $\begin{array}{l}\text { Landscaper, } \\
\text { alcoholism, } \\
\text { pancreatitis }\end{array}$ & 9/96: $11.9,1.2$ & $\begin{array}{l}\text { BE: concentric } \\
\text { stricture of } \\
\text { descending } \\
\text { colon; CT: } \\
\text { large intra-abd } \\
\text { mass, left } \\
\text { hepatic lobe } \\
\text { lesion }\end{array}$ & $\begin{array}{l}\text { 9/96: Resection } \\
\text { of mass, } \\
\text { descending colon, } \\
\text { biopsies of } \\
\text { liver and } \\
\text { retroperitoneum }\end{array}$ & $\begin{array}{l}\text { Itraconazole } \\
\text { (400 mg per } \\
\text { day for } 19 \\
\text { months) }\end{array}$ & $\begin{array}{l}\text { Asymptomatic; } \\
\text { no medication }\end{array}$ \\
\hline $3 / 56 / \mathrm{M}$ & $\begin{array}{l}\text { 2/98: Histo }+, \\
\text { culture }+\end{array}$ & $\begin{array}{l}\text { 9/97: Abd } \\
\text { pain; 11/97: } \\
\text { constipation, } \\
\text { abd mass }\end{array}$ & $\begin{array}{l}\text { IRDM, owns } \\
\text { trailer park } \\
\text { in a rural, } \\
\text { desert area }\end{array}$ & $11 / 97: 16.4,1.3$ & $\begin{array}{l}\text { Left } \\
\text { hydronephrosis, } \\
\text { retroperitoneal } \\
\text { infl }\end{array}$ & $\begin{array}{l}\text { 11/97: Subtotal } \\
\text { gastrectomy, } \\
\text { partial colectomy, } \\
\text { excision of mass; } \\
\text { 2/98: ascending } \\
\text { colon and mass } \\
\text { resection }\end{array}$ & $\begin{array}{l}\text { Itraconazole } \\
\text { (800 mg per } \\
\text { day for } 11 \\
\text { months), } \\
\text { terbinafine } \\
\text { (250 mg per } \\
\text { day for } 2 \\
\text { months) }\end{array}$ & $\begin{array}{l}\text { Asymptomatic; } \\
\text { no medication }\end{array}$ \\
\hline $4 / 52 / \mathrm{M}$ & $\begin{array}{l}\text { 12/98: Histo +, } \\
\text { culture }+\end{array}$ & $\begin{array}{l}\text { 10/98: Abd } \\
\text { pain }\end{array}$ & $\begin{array}{l}\text { Diabetes mellitus, } \\
\text { lived in same } \\
\text { trailer park } \\
\text { as case } 3 \text {, } \\
\text { high school } \\
\text { superintendent, } \\
\text { former smoker }\end{array}$ & $12.8,2.0(14 \%)$ & $\begin{array}{l}\text { BE: diverticula; } \\
\text { CT: sigmoid } \\
\text { colon diverticula, } \\
6 \times 10 \mathrm{~cm} \\
\text { sigmoid mass }\end{array}$ & $\begin{array}{l}\text { 12/98: Incomplete } \\
\text { excision of sigmoid } \\
\text { mass, adherent to } \\
\text { bladder and small } \\
\text { bowel; } \\
\text { 6/99: resection of } \\
\text { diseased sigmoid colon } \\
\text { and partial excision of } \\
\text { mass }\end{array}$ & $\begin{array}{l}\text { Itraconazole } \\
\text { (400 mg per } \\
\text { day for } 10 \\
\text { months) }\end{array}$ & $\begin{array}{l}\text { Asymptomatic; } \\
\text { no medication }\end{array}$ \\
\hline
\end{tabular}


Table 3. cont.

\begin{tabular}{|c|c|c|c|c|c|c|c|c|}
\hline $\begin{array}{l}\text { Patient no./age } \\
\text { (years)/sex }\end{array}$ & $\begin{array}{l}\text { Date and method } \\
\text { of GIB diagnosis }\end{array}$ & $\begin{array}{c}\text { Onset of } \\
\text { symptoms }\end{array}$ & $\begin{array}{l}\text { Medical and } \\
\text { social history }\end{array}$ & $\begin{array}{c}10^{-3} \times \mathrm{WBC} \\
\text { count }\left(\text { cells } \mathrm{ml}^{-1}\right) \\
\text { absolute eos count }\end{array}$ & $\begin{array}{l}\text { Radiological } \\
\text { findings }\end{array}$ & $\begin{array}{c}\text { Surgical } \\
\text { procedure(s) }\end{array}$ & Treatment & $\begin{array}{l}\text { Follow-up } \\
\text { findings }\end{array}$ \\
\hline $5 / 37 / \mathrm{F}$ & $\begin{array}{l}\text { 2/99: Histo +, } \\
\text { culture ND }\end{array}$ & 11/98: Abd pain & $\begin{array}{l}\text { Pica, respite } \\
\text { worker, smoker }\end{array}$ & $26.4,2.6$ & $\begin{array}{l}\text { CT: thickened } \\
\text { gastric walls, } \\
\text { intra-abd } \\
\text { lymph nodes }\end{array}$ & $\begin{array}{l}\text { 1/99: Subtotal } \\
\text { gastrectomy, } \\
\text { partial colectomy }\end{array}$ & $\begin{array}{l}\text { Itraconazole } \\
(400 \mathrm{mg} \text { per } \\
\text { day for } 9.5 \\
\text { months })\end{array}$ & $\begin{array}{c}\text { Asymptomatic; } \\
\text { no medication }\end{array}$ \\
\hline 6/59/M & $\begin{array}{l}\text { 2/99: Histo +, } \\
\text { culture+ }\end{array}$ & $\begin{array}{l}\text { 12/98: Mucus } \\
\text { in stool }\end{array}$ & $\begin{array}{l}\text { Pyloroplasty for } \\
\text { PUD, } \\
\text { thyroidectomy } \\
\text { (hypothyroid), } \\
\text { plumbing } \\
\text { contractor, } \\
\text { smoker }\end{array}$ & $12.1,0.7$ & $\begin{array}{l}\text { BE: sigmoid } \\
\text { colon stricture }\end{array}$ & $\begin{array}{l}\text { 1/99: Sigmoid } \\
\text { colon resection }\end{array}$ & $\begin{array}{l}\text { Itraconazole } \\
\text { (400 mg per } \\
\text { day for } 7 \\
\text { months })\end{array}$ & $\begin{array}{l}\text { Asymptomatic; } \\
\text { no medication }\end{array}$ \\
\hline 7/59/M & $\begin{array}{l}\text { 4/99: Histo +, } \\
\text { culture ND }\end{array}$ & $\begin{array}{l}\text { 3/99: } \\
\text { Constipation } \\
\text { abd pain }\end{array}$ & $\begin{array}{l}\text { IRDM, ESRD on } \\
\text { haemodialysis, } \\
\text { coronary heart } \\
\text { disease }\end{array}$ & Both elevated & $\begin{array}{l}\text { CT: caecal mass, } \\
\text { thickened sigmoid } \\
\text { colon wall }\end{array}$ & $\begin{array}{l}\text { 3/99: Excision of } \\
\text { mass, right colon } \\
\text { resection }\end{array}$ & $\begin{array}{l}\text { Itraconazole } \\
\text { (for } 10 \text { months) }\end{array}$ & Recovering \\
\hline
\end{tabular}


histological features. There are no apparent risk factors for this disease. Surgery is usually required, followed by prolonged antifungal therapy, and the preferred drug is itraconazole. The prognosis is uncertain because of the insidious progression of the disease and its delayed diagnosis. Better familiarity with this condition may prevent a fatal outcome. Further studies are awaited for better defining of its risk factors and best modalities of diagnosis and treatment.

\section{References}

Al Jarie, A., Al-Mohsen, I., Al Jumaah, S., Al Hazmi, M., Al Zamil, F., Al Zahrani, M., Al Modovar, E., Al Dayel, F., Al Arishii, H. \& other authors (2003). Pediatric gastrointestinal basidiobolomycosis. Pediatr Infect Dis J 22, 1007-1014.

Arney, G. K., Pearson, E. \& Sutherland, A. B. (1960). Burn stress pseudodiabetes. Ann Surg 152, 77-90.

Bigliazzi, C., Poletti, V., Dell'Amore, D., Saragoni, L. \& Colby, T. V. (2004). Disseminated basidiobolomycosis in an immunocompetent woman. J Clin Microbiol 42, 1367-1369.

Bittencourt, A. L., Londero, A. T., Araujo, M. S., Mendonca, N. \& Bastos, J. L. (1979). Occurrence of subcutaneous zygomycosis caused by Basidiobolus haptosporus in Brazil. Mycopathologia 68, 101-104.

Cameroon, H. M. (1990). Entomophthoromycosis. In Tropical Mycoses, pp. 186-198. Edited by E. S. Mahgoub. Beerse, Belgium: Janssen Research Council.

Chandler, F. W. \& Watts, J. C. (1987). Pathologic Diagnosis of Fungal Infections, pp. 85-95. Chicago, IL: ASCP Press.

Clark, B. M. (1968). Epidemiology of phycomycosis. In Systemic Mycoses, pp. 179-192. Edited by G. E. W. Wolstenhome \& R. Porter. Boston, MA: Little, Brown \& Co.

de Aguiar, E., Moraes, W. C. \& Londero, A. T. (1980). Gastrointestinal entomophthoramycosis caused by Basidiobolus haptosporus. Mycopathologia 72, 101-105.

Drechsler, C. (1956). Supplementary developmental stages of Basidiobolus ranarum and Basidiobolus haptosporus. Mycologia 48, 655-677.

Dworzack, D. L., Pollock, A. S., Hodges, G. R., Barnes, W. G., Ajello, L. \& Padhye, A. (1978). Zygomycosis of the maxillary sinus and palate caused by Basidiobolus haptosporus. Arch Intern Med 138, 1274 1276

Echetebu, C. O. \& Ononogbu, I. C. (1982). Extracellular lipase and proteinase of Basidiobolus haptosporus: possible role in subcutaneous mycosis. Mycopathologia 80, 171-177.

Edington, G. M. (1964). Phycomycosis in Ibadan, Western Nigeria: two post-mortem reports. Trans R Soc Trop Med Hyg 58, 242-245.

El-Shabrawi, M. H., Kamal, N. M., Jouini, R., Al-Harbi, A., Voigt, K. \& AlMalki, T. (2011). Gastrointestinal basidiobolomycosis: an emerging fungal infection causing bowel perforation in a child. J Med Microbiol 60 (in press).

Fahimzad, A., Karimi, A., Tabatabaei, S. R. \& Zadeh, M. G. (2006). Gastrointestinal basidiobolomycosis as a rare etiology of bowel obstruction. Turk J Med Sci 36, 239-241.

Finelli, A., Rasul, I., Keystone, J. \& Bargman, J. M. (1997). Development of severe secondary hypertension in a patient with systemic entomophthoromycosis. Am J Kidney Dis 29, 620-623.

Goodman, N. L. \& Rinaldi, M. G. (1991). Agents of zygomycosis. In Manual of Clinical Microbiology, 5th edn, pp. 674-692. Edited by
A. Balows, W. J. Hausler, K. L. Herrmann, H. D. Isenberg \& H. J. Shadoomy. Washington, DC: American Society for Microbiology.

Greer, D. L. \& Friedman, L. (1966). Studies on the genus Basidiobolus with reclassification of the species pathogenic to man. Sabouraudia 4 , 231-241.

Gruhn, J. G. \& Sanson, J. (1963). Mycotic infections in leukemic patients at autopsy. Cancer 16, 61-73.

Gugnani, H. C. (1983). The pattern of deep mycoses in Nigeria. West Afr J Med 2, 67-71.

Hussein, M. R., Musalam, A. O., Assiry, M. H., Eid, R. A., El Motawa, A. M. \& Gamel, A. M. (2007). Histological and ultrastructural features of gastrointestinal basidiobolomycosis. Mycol Res 111, 926-930.

Kamalam, A. \& Thambiah, A. S. (1984). Muscle invasion by Basidiobolus haptosporus. Sabouraudia 22, 273-277.

Kamalam, A., Sentamilsilvi, G. \& Thambiah, A. S. (1992). Entomophthoromycosis. Proc R Coll Physicians Edinb 22, 52-59.

Khan, Z. U., Prakash, B., Kapoor, M. M., Madda, J. P. \& Chandy, R. (1998). Basidiobolomycosis of the rectum masquerading as Crohn's disease: case report and review. Clin Infect Dis 26, 521-523.

Khan, Z. U., Khoursheed, M., Makar, R., Al-Waheeb, S., Al-Bader, I., Al-Muzaini, A., Chandy, R. \& Mustafa, A. S. (2001). Basidiobolus ranarum as an etiologic agent of gastrointestinal zygomycosis. J Clin Microbiol 39, 2360-2363.

Kian Joe, L., Pohan, A., Tjoei Eng, N. I. \& Van Der Meulen, H. (1956). Basidiobolus ranarum as a cause of subcutaneous mycosis in Indonesia. AMA Arch Dermatol 74, 378-383.

Kwon-Chung, K. J. \& Bennett, J. E. (1992). Medical Mycology, pp. 449-463. Philadelphia: Lea \& Febiger.

Lyon, G. M., Smilack, J. D., Komatsu, K. K., Pasha, T. M., Leighton, J. A., Guarner, J., Colby, T. V., Lindsley, M. D., Phelan, M. \& other authors (2001). Gastrointestinal basidiobolomycosis in Arizona: clinical and epidemiological characteristics and review of the literature. Clin Infect Dis 32, 1448-1455.

Miller, R. \& Pott, B. (1980). Phycomycosis of the horse caused by Basidiobolus haptosporus. Aust Vet J 56, 224-227.

Miller, R. I. \& Turnwald, G. H. (1984). Disseminated basidiobolomycosis in a dog. Vet Pathol 21, 117-119.

Mugerwa, J. W. (1976). Subcutaneous phycomycosis in Uganda. $\mathrm{Br} J$ Dermatol 94, 539-544.

Nazir, Z., Hasan, R., Pervaiz, S., Alam, M. \& Moazam, F. (1997). Invasive retroperitoneal infection due to Basidiobolus ranarum with response to potassium iodide - case report and review of the literature. Ann Trop Paediatr 17, 161-164.

Nguyen, B. D. (2000). CT features of basidiobolomycosis with gastrointestinal and urinary involvement. AJR Am J Roentgenol 174, 878-879.

Okafor, J. I. (1994). Purification and characterization of protease enzymes of Basidiobolus and Conidiobolus species. Mycoses 37, 265-269.

Okafor, J. I. \& Gugnani, H. C. (1990). Lipase activity of Basidiobolus and Conidiobolus species. Mycoses 33, 81-85.

Okafor, J. I., Gugnani, H. C., Testratke, D. \& Yangoo, B. G. (1987). Extracellular enzyme activities by Basidiobolus and Conidiobolus isolates on solid media. Mykosen 30, 404-407.

Pasha, T. M., Leighton, J. A., Smilack, J. D., Heppell, J., Colby, T. V. \& Kaufman, L. (1997). Basidiobolomycosis: an unusual fungal infection mimicking inflammatory bowel disease. Gastroenterology 112, 250-254.

Reinhardt, D. J., Kaplan, W. \& Ajello, L. (1970). Experimental cerebral zygomycosis in alloxan-diabetic rabbits I. Relationship of temperature tolerance of selected zygomycetes to pathogenicity. Infect Immun 2, $404-413$. 
Schmidt, J. H., Howard, R. J., Chen, J. L. \& Pierson, K. K. (1986). First culture-proven gastrointestinal entermophthoromycosis in the United States: a case report and review of the literature. Mycopathologia 95, 101-104.

St Germain, G. \& Summerbel, R. (1996). Identification of Filamentous Fungi: a Clinical Laboratory Handbook, pp. 80-81. Belmont, CA: Star Publishing.

Sugar, A. M. (1990). Agents of mucormycosis and related species. In Principles and Practice of Infectious Diseases, 3rd edn, pp. 1962-1972. Edited by G. L. Mandell, R. G. Douglas \& J. E. Bennett. New York: Churchill Livingstone.

Sugar, A. M. (1995). Agents of mucormycosis and related species. In Mandell, Douglas and Bennett's Principles and Practice of Infectious Diseases, 4th edn, vol. 2, pp. 2311-2321. Edited by G. L. Mandell, J. E. Bennett \& R. Dolin. New York: Churchill Livingstone.

Sutherland-Campbell, H. (1929). An attempt to prove the etiologic factor in an epidemic among orange workers. Arch Derm Syphilol 19, 233-254.

Thaxter, R. (1888). The Entomophthoreae of the United States. Memoirs of the Boston Society of Natural History, vol. IV, pp. 133-201. Boston: Boston Society of Natural History.

van den Berk, G. E., Noorduyn, L. A., van Ketel, R. J., van Leeuwen, J., Bemelman, W. A. \& Prins, J. M. (2006). A fatal pseudo-tumour: disseminated basidiobolomycosis. BMC Infect Dis 6, 140.
Vismer, H. F., de Beer, H. A. \& Dreyer, L. (1980). Subcutaneous phycomycosis caused by Basidiobolus haptaosporus (Drechsler, 1947). S Afr Med J 58, 644-647.

Wardlaw, A. J. \& Kay, A. B. (1995). Eosinopenia and eosinophilia. In Williams Hematology, pp. 844-852. Edited by E. Beutler, M. A. Lichtman, B. S. Coller \& T. J. Kipps. New York: McGraw Hill.

Wasim Yusuf, N., Assaf, H. M. \& Rotowa, N. A. (2003). Invasive gastrointestinal Basidiobolus ranarum infection in an immunocompetent child. Pediatr Infect Dis J 22, 281-282.

Yangco, B. G., Nettlow, A., Okafor, J. I., Park, J. \& Te Strake, D. (1986). Comparative antigenic studies of species of Basidiobolus and other medically important fungi. J Clin Microbiol 23, 679682.

Yousef, O. M., Smilack, J. D., Kerr, D. M., Ramsey, R., Rosati, L. \& Colby, T. V. (1999). Gastrointestinal basidiobolomycosis. Morphologic findings in a cluster of six cases. Am J Clin Pathol 112, 610-616.

Zahari, P., Hirst, R. G., Shipton, W. A. \& Campbell, R. S. F. (1990). The origin and pathogenicity of Basidiobolus species in northern Australia. J Med Vet Mycol 28, 461-468.

Zavasky, D. M., Samowitz, W., Loftus, T., Segal, H. \& Carroll, K. (1999). Gastrointestinal zygomycotic infection caused by Basidiobolus ranarum: case report and review. Clin Infect Dis 28, 12441248. 